\title{
PEMENUHAN HAK PEKERJA ATAS KELEBIHAN WAKTU KERJA PADA SAYAN POINT RESTAURANT
}

\author{
Ni Made Gina Anggreni, Fakultas Hukum Universitas Udayana, e-mail: \\ ginaanggreni17@yahoo.co.id \\ I Made Sarjana, Fakultas Hukum Universitas Udayana, e-mail: \\ made_sarjana@unud.ac.id
}

doi: https://doi.org/10.24843/KS.2020.v08.i09.p04

\begin{abstract}
ABSTRAK
Tujuan yang penulis ingin capai dalam jurnal ini adalah untuk mengkaji hak yang seharusnya diperoleh oleh pekerja yang melebihi batas waktu kerja dan mengkaji berbagai faktor yang menyebabkan sulitnya pemenuhan hak atas pekerja yang melebihi batas waktu kerja. Penelitian jurnal ini menggunakan metode penelitian hukum empiris yakni melakukan pengamatan terhadap suatu peraturan perundang-undangan yang ada terhadap pelaksanaan suatu aturan dalam masyarakat. Hasil penelitian pada Sayan Point Restaurant menunjukkan bahwa beberapa ketentuan terkait pemenuhan hak pekerja atas kelebihan waktu kerja belum terpenuhi penggunaan perintah tertulis, pemberian makan saat lembur. Faktor penghambat terhadap pelaksanaan pembayaran upah lembur yang tidak diberikan serta pemberian makan saat lembur yang lebih dari 3 jam, pemilik restoran dan pekerja kurang mengetahui mengenai adanya pengaturan tersebut.
\end{abstract}

Kata Kunci: Hak Pekerja, Batas Waktu Kerja, Perlindungan Pekerja

\begin{abstract}
The purpose of the author want to achieve in this journal is to examine the rights that should be obtained by workers who exceed the work time limit and examine various factors that make it difficult to fulfill the rights to workers who exceed the work time limit. This research journal uses an empirical method that is observing an existing legislation regarding the implementation of a rule in society. The results showed at Sayan Point Restaurant that several provisions related to the fulfillment of workers' rights to excess work time had not yet been met the use of written instructions, feeding on overtime. Obstacles to the implementation of payment of overtime wages that are not given as well as feeding overtime for more than 3 hours, restaurant owners and workers are less aware of the regulation.
\end{abstract}

\section{Keywords: Worker Rights, Work Deadline, Worker Protection}

\section{Pendahuluan}

\subsection{Latar Belakang Masalah}

Pembangunan dalam meningkatkan pertumbuhan perekonomian nasional terjadi berdasarkan kualitas tenaga kerja yang dimiliki sebagai pelaku dan tujuan pembangunan, karena tenaga kerja memegang peranan dalam meningkatkan pertumbuhan perekonomian diharapkan terus meningkat setiap tahunnya. ${ }^{1}$ Setiap orang berhak untuk bisa bekerja berdasarkan keahlian yang mereka miliki untuk meningkatkan kesejahteraan hidup pekerja dan keluarga. Dalam Undang-Undang

1 Jayanti, Feranika Anggasari, and I. Made Udiana. "Perlindungan Hukum Terhadap Tenaga Kerja Perempuan Pada Malam Hari Di Hotel Kelas Melati (Studi Pada Hotel Jayagiri Denpasar)." Kertha Semaya: Journal Ilmu Hukum 5, no. 2 (2017): 1-6. 
Negara Republik Indonesia 1945 (UUD NRI 1945) hak mengenai seseorang dalam memperoleh suatu pekerjaan yang digunakan untuk keperluan agar dapat hidup sesuai dengan kebutuhan hidup yang layak telah diatur pada Pasal 27 ayat (2) menyatakan bahwa "tiap-tiap warga negara berhak atas pekerjaan dan penghidupan yang layak bagi kemanusiaan." Perlindungan terhadap pemberian hak pekerja pada, "Universal Declaration of Human Rights" UDHR diatur dalam Article 23 menyatakan bahwa:

"(1) Everyone has the right to work, to free choise of employment, to just and favourable conditions of work and to protection against unemployment.

(2) Everyone, without any discrimination, has the right to equal pay for work.

(3) Everyone who works has the right to just and favourable remuneration ensuring for himself and his family an existence worthy of human dignity, and supplemented, if necessary, by oter means of social pretection.

(4) Everyone has the right to form an to join trade unions for the protection of his interests".

Tenaga kerja merupakan penentu keberhasilan dalam setiap perusahaan serta elemen yang tidak dapat dihilangkan dalam sektor pembangunan, produksi dan jasa. Seiring perkembangan teknologi yang semakin canggih, perkembangan sektor industri pariwisata mempengaruhi pola jasa dan distribusi masyarakat, industri pariwisata banyak dipilih oleh beberapa orang, perusahaa, investor untuk mengembangkan bisnisnya. Industri pariwisata merupakan industri yang menjanjikan bagi masyarakat untuk mendapatkan pekerjaan dan bagi negara, pariwisata merupakan salah satu pemasukan untuk negara. Salah satu aspek pendukung dalam usaha pariwisata yang sedang berkembang adalah restoran. Dengan berkembangnya bisnis restoran, hal ini mampu menyerap tenaga kerja yang memiliki kemampuan ataupun skill dibidang yang menjadi kompetensinya untuk dapat bekerja di restoran. Secara yuridis hubungan hukum yang terjalin oleh pekerja pemberi kerja mempunyai derajat yang sama di dalam hukum, keduanya telah mempunyai kewajiban yang sudah seharusnya untuk dilaksanakan serta memiliki hak yang semestinya untuk didapatkan. Terciptanya perjanjian kerja, mampu mengikat pihak-pihak yang memiliki hubungan dalam bidang ketenagakerjaan yakni, pekerja dengan pengusaha yang telah memenuhi unsur-unsur dalam ketentuan undang-undang serta memiliki akibat hukum. Ketentuan terhadap perlindungan hukum bagi pekerja di Indonesia, telah diatur pada hukum positif Indonesia ataupun pada hukum internasional sangat diperlukan dan menjadi perhatian bagi tenaga kerja guna mempelajari serta memahami terhadap hak yang dimiliki oleh pekerja yang telah diatur oleh hukum, hal ini dilakukan untuk mencegah suatu tindakan yang mengakibatkan ketidakadilan dari pihak pemberi kerja. ${ }^{2}$

Konvensi internasional seperti ICESCR, ICCPR serta ILO telah mengatur hak tenaga kerja secara internasional. ${ }^{3}$ International Covenant on Civil and Political Rights (ICCPR) memberikan penjelasan secara umum tentang hak untuk berserikat bagi para pekerja yang diatur pada Article 22 ICCPR serta hak non diskriminasi pada Article 26. International Covenant on Economic, Social, and Cultural Rights (ICESCR) mengatur

2 Pratama, Ida Bagus Gede, and I. Nyoman Darmadha. "Pelaksanaan Istirahat Kerja Bagi Pekerja Perempuan Pada Ramayana Hotel Denpasar." Kertha Negara: Journal Ilmu Hukum 7, no. 10 (2019) : 1-15.

3 Mantiri, Frangky F. "Perlindungan Hukum Pemda Sulawesi Utara Atas Hak Dasar Tenaga Kerja Sebagai Wujud Perlindungan Hak Asasi Manusia." Lex Et Societatis 6, no. 3 (2018): 1-9. 
mengenai hak pekerja pada Article 6 dan Article 7 mengatur mengenai upah yang layak diterima oleh pekerja. ${ }^{4}$ Konvensi International Labour Organization (ILO) telah mengatur lebih khusus mengenai hak-hak pekerja bagi perempuan. Beberapa acuan standar yang diterpkan oleh ILO untuk menjamin hak pekerja khususnya bagi perempuan yakni kesetaraan upah, diskriminasi dalam pekerjaan dan jabatan, perlindungan kehamilan, dan pekerja dengan tanggung jawab keluarga. ${ }^{5}$ Kewajiban terhadap sesuatu pekerjaan yang harus dilakukan dan hak sebagaimana yang semestinya didapatkan dari para pihak telah diatur pada Undang-Undang Nomor 13 Tahun 2003 Tentang Ketenagakerjaan serta peraturan pelaksananya, mengenai kesepakatan-kesepakatan para pihak dituangkan kedalam suatu perjanjian pada hubungan kerja dapat dilakukan dengan menggunakan perjajian kerja tertulis atau lisan. UU Ketenagakerjaan mengatur beberapa aspek seperti waktu kerja, upah, perlindungan pemenuhan hak bagi pekerja. Pasal 77 ayat (2) Undang-Undang Ketenagakerjaan telah mengatur mengenai waktu kerja yakni " 7 (tujuh) jam 1 (satu) hari dan 40 (empat puluh) jam 1 (satu) minggu untuk 6 (enam) hari kerja dalam 1 (satu) minggu; atau 8 (delapan) jam 1 (satu) hari dan 40 (empat puluh) jam 1 (satu) minggu untuk 5 (lima) hari kerja dalam 1 (satu) minggu". Waktu yang ditentukan dalam melakukan pekerjaan disebut waktu kerja. Waktu kerja menjadi salah satu unsur untuk diperhatikan. Pekerja perlu untuk memperhatikan waktu kerja, karena untuk menjaga kesehatan fisik serta psikisnya sehingga pekerja memerlukan waktu untuk beristirahat dengan cukup. Money oriented merupakan prinsip yang umum untuk dikejar oleh restoran. Pemilik restoran seringkali melakukan waktu kerja tidak sesuai dengan undang-undang dengan melakukan penambahan jam kerja bagi pekerjanya. ${ }^{6}$ Bagi pekerja yang melakukan penambahan jam kerja atau sering disebut dengan istilah lembur, pekerja memiliki hak-hak yang semestinya untuk didapatkan pada saat lembur seperti makan, minum, pembayaran upah yang berbeda dengan gaji pokok, sesuai dengan Kepmenakertrans No. KEP-102/MEN/IV/2004 Tahun 2004 Tentang Waktu Kerja Lembur Dan Upah Kerja Lembur. Pengusaha wajib membayar upah bagi pekerja, apabila mempekerjakan pekerja yang telah melebihi waktu saat bekerja. ${ }^{7}$

Pada Sayan Point Restaurant Ubud, pekerja yang bekerja di Sayan Point Restaurant menggunakan perjanjian kerja lisan, masa percobaan yang telah dilaksanakan oleh pemilik restoran terhadap pekerja yang hendak bekerja yakni 3 bulan. Penggunaan perjanjian bagi suatu pekerjaan bagi para pihak antara pekerja dengan pemberi kerja dapat menggunakan perjanjian kerja dalam bentuk perjanjian kerja lisan, poin-poin yang telah disepakati berupa hal-hal yang secara umum seperti mengenai jam kerja, kewajiban dan hak dari pekerja, gaji pokok yang sesuai dengan UMK. Dalam pengunaan perjanjian kerja lisan akan mempersulit pekerja untuk

4 Ismono, Joko. "Hubungan Kerja dalam Perspektif HAM, Ekonomi, dan Pembangunan." Halu Oleo Law Review 2, no 1 (2018): 354-370.

5 Rismansyah, Mohammad Robi, and Yasmin Hadid. "Hak Pekerja Perempuan Diskriminasi. "Perlindungan Hukum Terhadap Tenaga Kerja Perempuan Indonesia Di Tempat Kerja Dan Kaitannya Dengan Pembangunan Ekonomi Nasional." Padjajaran Jurnal Ilmu Hukum 7, no 2 (2019): 26-43.

6 Opriyana, I. Ketut Agus Surya, I. Made Udiana, and I. Nyoman Mudana. "Pelaksanaan Ketentuan Upah Lembur Pekerja Pada CV. Bali Aquarium." Kertha Semaya: Journal Ilmu Hukum 6, no. 12 (2019): 1-14.

7 Tricahya, Anak Agung Ngurah Gede Agung, Yoga Kumara, and I. Wayan Novy Purwanto. "Korelasi Antara Waktu Kerja Lembur Terhadap Upah Yang Terjadi Di Lingkungan Masyarakat Waribang." Kertha Semaya: Journal Ilmu Hukum 4, no. 1 (2018): 1-14. 
menuntut hak-haknya yang tidak sesuai karena tidak adanya bukti tertulis yang dipegang. Pelaksanaan kerja yang melebihi waktu kerja terdapat beberapa pengabaian mengenai ketentuan-ketentuan yang semestinya diketahui dan didapatkan oleh pekerja. Dalam pelaksanaan kerja yang melebihi waktu kerja seharusnya pekerja terdapat pemberitahuan yang diwujudkan dengan perintah tertulis dan adanya persetujuan dari pekerja yang kemudian ditandatangai, membayar upah, mendapatkan makan beserta minum minimal 1.400 kalori, memberi kesempatan untuk melakukan istirahat. Pembayaran upah bagi pekerja yang diberikan oleh pemilik perusahaan wajib memberikan bukti yang digunakan untuk pembayaran upah pekerja yang memberikan berbagai rincian terhadap upah yang semestinya diterima bagi pekerja ketika upah tersebut diberikan. PP Tentang Pengupahan Nomor 78 Tahun 2015 , Pasal 17 ayat (2) telah mengatur mengenai suatu perusahaan yang memiliki kewajiban dalam memberikan upah atau gaji untuk pekerja harus memberikan rincian mengenai spesifikasi upah yang diberikan, namun jika dilihat sepertinya kebayakan bahwa tenaga kerja apabila sudah mendapatkan gaji sesuai dengan standar upah atau yang lumrah disebut dengan upah minimum dan mampu memenuhi kebutuhan untuk hidup yang layak, maka pekerja akan menerima tanpa mempertanyakan mengenai upah yang diterimanya. Pada Sayan Point Restauran tidak memberian rincian mengenai rincian upah apa saja yang didapatkan oleh pekerja.

Pelaksanaan suatu perusahaan dalam memberikan gaji untuk pekerja yang melakukan pekerjaan melewati ketentuan batas jam kerja, pelaksanaan lembur dengan tidak adanya perintah tertulis, pekerja yang seharusnya mendapatkan makan dan minum, serta dalam pemberian gaji yang tidak diberikan rincian gaji yang diterima oleh pekerja, terdapat beberapa tulisan karya ilmiah memiliki keterkaitan dengan isu hukum diatas antara lain: Ni Made Rosa Dita Andriani yang membahas mengenai pelaksanaan hak tenaga kerja kontrak dan membehas mengenai pemberian makan pada kerja lembur yang diganti dengan uang. ${ }^{8}$ Pada tulisan Pande Md. Meby Elbina Devita Cesmi mengkaji mengenai dalam pelaksanaan lembur, perusahaan meminta persetujuan untuk melakukan kerja lembur serta membahas pembayaran upah lembur yang menggunakan sistem harian dan bagi pekerja tetap. ${ }^{9}$ Lebih lanjut dalam jurnal I Ketut Agus Surya Opriyana membahas mengenai pelaksanaan waktu kerja lembur dengan persetujuan oleh para pekerja serta dalam karya tulisnya tersebut mengemukakan bahwa pekerja yang lembur tidak dibayar. ${ }^{10}$ Berdasarkan penulisan jurnal yang mengkaji mengenai pekerja yang melakukan lembur, belum membahas mengenai kewajiban perusahaan untuk membayar gaji kepada pekerja yang merupakan haknya dengan rincian upah yang menjadi kewajiban pemberi kerja untuk dibayarkan. Oleh karena itu menarik untuk dikaji lebih dalam mengenai kewajiban pemberi kerja untuk memenuhi hak pekerja yang telah melampaui ketentuan terhadap waktu kerja serta memberikan rincian dalam pemberian upah bagi pekerja.

8 Andriani, Ni Made Rosa Dita, and I Ketut Sudantra. "Pelaksanaan Perlindungan Hukum Terhadap Hak Tenaga Kerja Kontrak Pada Hotel The Griya Sanur." Journal Ilmu Hukum 8, no. 4 (2020): 1-13.

9 Cesmi, Pande Md. Meby Elbina Devita Cesmi, and A.A. Gede Agung DharmaKusuma. "Perlindungan Hukum Terhadap Tenaga Kerja Yang Bekerja Melebihi Batas Waktu Lembur Pada Perusahaan PT. Bintang Merapi Denpasar." Journal Ilmu Hukum 01, no. 11 (2013): 1-15.

10 Opriyana, I. Ketut Agus Surya, I. Made Udiana, and I. Nyoman Mudana. Op.Cit: 1-14. 


\subsection{Rumusan Masalah}

Berdasarkan pemaparan pendahuluan diatas, maka beberapa rumusan masalah yang dikaji dalam artikel ini adalah sebagai berikut:

1) Bagaimana pemenuhan hak pekerja atas kelebihan waktu kerja pada Sayan Point Restaurant?

2) Apakah yang menjadi faktor penghambat dalam pelaksanaan terhadap pemenuhan hak pekerja yang melebihi batas waktu kerja pada Sayan Point Restaurant?

\subsection{Tujuan Penulisan}

Tujuan yang penulis ingin capai dalam jurnal ini adalah untuk mengkaji lebih dalam mengenai pemenuhan hak pekerja yang kelebihan waktu kerja pada Sayan Point Restaurant serta untuk mengetahui faktor penghambat dalam pelaksanaan pemenuhan hak pekerja yang melebihi batas waktu kerja pada Sayan Point Restaurant

\section{Metode Penelitian}

Metode penelitian dalam tulisan ini menggunakan metode penelitian hukum empiris. Pengkajian yang dilakukan dengan metode hukum empiris yakni melakukan pengamatan terhadap suatu peraturan perundang-undangan yang ada terhadap pelaksanaan suatu aturan dalam masyarakat (dasollen dan dassein). Penelitian hukum empiris melihat perubahan-perubahan sosial yang terjadi berdasarkan kesesuaian dengan peruraturan yang ada serta melihat eksistensi hukum dan fungsi hukum dalam masyarakat.11 Penggunaan data primer yang digunakan merupakan hasil wawancara yang telah dilakukan dengan seseorang yang memiliki kompetensi atau informan yang memiliki keterkaitan dengan masalah yang diangkat, sedangkan penggunaan data sekunder termasuk diantaranya dalam bahan hukum primer terdiri dari peraturan-peraturan, sedangkan yang termasuk kedalam bahan hukum sekunder antara lain jurnal, website resmi, buku yang memiliki keterkaitan dengan masalah ketenagakerjaan yang diangkat.

\section{Hasil dan Pembahasan}

\subsection{Pemenuhan Hak Pekerja Atas Kelebihan Waktu Kerja Pada Sayan Point Restaurant}

Pekerja berhak dalam memperoleh suatu perlindungan yang sama didalam hukum, pekerja memiliki hak dasar dilakukan untuk menjamin agar pekerja tidak mendapatkan perlakuan yang merugikan dirinya seperti tindakan diskriminasi serta tidak mendapatkan kesejahteraan ataupun keselamatan kerja bagi pekerja. Satjipto Raharjo mengemukakan terkait definisi perlindungan hukum yaitu "memberikan pengayoman kepada hak asasi manusia yang dirugikan orang lain dan perlindungan tersebut diberikan kepada masyarakat agar mereka dapat menikmati semua hak-hak yang diberikan oleh hukum". Hubungan industrial dalam undang-undang ketenagakerjaan sehingga perlu dikembangkan prinsip-prinsip dasar yang terkandung didalamnya, sehingga memiliki arah tujuan untuk terciptanya sistem serta kelembagaan yang ideal dalam membangun

11 Wiradipradja, E. Saefullah. Penuntun Praktis Metode Penelitian Dan Penulisan Karya Ilmiah Hukum Cetakan Ke 2 (Bandung, CV Keni Media, 2016), 34. 
suatu kondisi kerja yang profitable, selaras, dinamis serta berkeadilan. ${ }^{12}$ Perlindunggan hak terhadap tenaga kerja juga diwujudkan untuk mengembangkan dunia usaha serta melindungi dunia usaha sebagai pemberi kerja. Terdapat tiga macam perlindungan bagi tenaga kerja, antara lain: ${ }^{13}$

1. Perlindungan ekonomis, yaitu terhadap pekerja mempunyai suatu hak guna memperoleh perlindungan berupa penghasilan yang cukup untuk memenuhi kehidupan yang layak.

2. Perlindungan sosial, yaitu pekerja untuk mendapatkan perlindungan berupa jaminan kesehatan kerja, perlindungan dalam berorganisasi.

3. Perlindungan teknis, yaitu terhadap pekerja mendapatkan perlindungan keselamatan dan keamanan kerja.

Undang-Undang Nomor 13 Tahun 2003 Tentang Ketenagakerjaan mengatur bahwa pengusaha sebagai pememberi kerja beserta pekerja memuat syarat kerja bagi pekerja yang harus dilaksanakan, disisi lain mengenai hak dan kewajiban bagi para pihak dapat disepakati dan diatur pada hubungan kerja. Hubungan kerja memiliki unsur yang tidak dapat dipisahkan yakni unsur pekerjaan, perintah dan upah. Terjadinya hubungan kerja oleh pemberi kerja terhadap pekerja dapat dilakukan, namun adanya terciptanya hubungan kerja harus pula diadakan perjanjian kerja. ${ }^{14}$ Pasal 1320 KUHPerdata merupakan syarat sah terhadap suatu perjanjian yang dibuat oleh para pihak. Mengenai sahnya perjanjian kerja harus disepakati antara pemberi kerja beserta pekerja telah diatur pada Pasal 52 ayat (1) Undang-Undang Ketenagakerjaan, pihak yang bersepakat untuk melakukan perjanjian kerja sehingga menimbulkan hak dan kewajiban. Perusahaan yang mempekerjakan beberapa orang pekerja dengan memiliki hubungan kerja yang telah disepakati berhak untuk memperoleh gaji serta hak yang telah termaktub pada undang-undang ketenagakerjaaan ataupun pada perjanjian yang telah disepakati antara pekerja dengan perusahaan. ${ }^{15}$ Pada suatu pekerjaan yang menjadi hal penting untuk diperhatikan adalah waktu kerja. ${ }^{16}$ Pada undang-undang ketenagakerjaan waktu kerja untuk pekerja dituangkan pada Pasal 77 ayat (2), waktu kerja yang telah ditetapkan yakni "7 (tujuh) jam 1 (satu) hari dan 40 (empat puluh) jam 1 (satu) minggu untuk 6 (enam) hari kerja dalam 1 (satu) minggu; atau 8 (delapan) jam 1 (satu) hari dan 40 (empat puluh) jam 1 (satu) minggu untuk 5 (lima) hari kerja dalam 1 (satu) minggu".

Perusahaan dalam melakukan sistem lembur memiliki suatu kewajiban yang telah ditentukan dalam Kepmenakertrans No. KEP-102/MEN/IV/2004 Tahun 2004 Tentang Waktu Kerja Lembur Dan Upah Kerja Lembur, Pasal 6 telah ditentukan bahwa bagi pekerja yang akan melaksanakan lembur maka perusahaan harus ada

12 Sudewi, Komang Ritha, and A.A. Ngurah Wirasila. "Penyelesaian Sengketa Perjanjian Kerja Pada Pekerja Di Hotel Kubu Bali House Di Kabupaten Badung." Kertha Semaya: Journal Ilmu Hukum 4, no. 2 (2018): 1-14.

13 Sumandika, I. Wayan Agus, and I. Nyoman Mudana. "Pelaksanaan Perlindungan Hukum Bagi Pekerja Perempuan Pada Besakih Beach Hotel Sanur Di Denpasar." Kertha emaya: Journal Ilmu Hukum 7, no. 2 (2019) : 1-20.3.

14 Husni, Lalu. Pengantar Hukum Ketenagakerjaan Edisi Revisi (Depok, PT RajaGrafindo Persada, 2019), 62.

15 Putri, Ni Nyoman Nityarani Sukadana, and Ni Ketut Supasti Dharmawan. "Pengaturan Hak Pekerja Yang Di PHK Berkaitan Dengan Perusahaan Pailit." Kertha Semaya: Journal Ilmu Hukum 6, no. 11 (2018) : 1-15.

16 Setiawan, Andre. "Pemenuhan Hak Pekerja Outsourcing Yang Bekerja Melebihi Waktu Kerja Normal Di PT Trakindo Utama Balikpapan." Universitas Atma Jaya Yogyakarta (2014): 1-9. 
perintah tertulis yang telah disetujui oleh pekerja, perintah tertulis tersebut dapat dibuat oleh perusahaan berupa suatu daftar kerja terhadap pekerja yang menyetujui untuk kerja lembur kemudian pekerja yang telah menyetujui untuk kerja lembur menandatangani daftar kerja yang telah dibuat sebagai persetujuan untuk kerja lembur. Pada Pasal 7 telah ditentukan bahwa untuk melakukan waktu kerja lembur, perusahaan memiliki kewajiban untuk memberikan upah terhadap pelaksanaan atas kerja lembur kepada pekerja, pemberian istirahat yang cukup kemudian makan serta minum minimal 1.400 kalori apabila melakukan lembur lebih dari 3 jam. Pekerja memiliki hak untuk menerima atau menolak kerja lembur, pemberi kerja tidak dapat memaksa pekerja melaksanakan lembur karena pekerja memiliki hak untuk menolaknya. Dalam peraturan perundang-undangan khususnya yang mengatur mengenai ketenagakerjaan telah diatur batas waktu kerja, sehingga bagi pengusaha wajib memberlakukan peraturan tersebut. Melakukan pekerjaan diluar jam kerja oleh pekerja, yang telah ditentukan oleh pemberi kerja maka waktu kerja tersebut dapat dikatakan sebagai lembur, sehingga pekerja memiliki hak untuk memperoleh upah lembur diluar gaji pokok.17 Pekerja yang melebihi jam kerja untuk melakukan pekerjaan, perusahaan sebagai pemberi kerja memiliki kewajiban untuk melakukan pembayaran upah kerja lembur maupun pemenuhan hak yang menjadi tanggung jawab pemberi kerja. Dalam Peraturan Pemerintah Nomor 78 Tahun 2015 Tentang Pengupahan, Pasal 17 ayat (2) telah mengatur bahwa suatu perusahaan yang memberikan upah atau gaji kepada pekerja harus memberikan rincian mengenai spesifikasi upah yang diberikan.

Sayan Point Restaurant merupakan salah satu restoran yang bertempat di desa Sayan, kecamatan Ubud. Berdasarkan hasil wawancara dengan ibu Ni Wayan Astiti sebagai pemilik Sayan Point Restaurant, pada 26 Maret 2020. Pekerja Sayan Point Restaurant tersebut merupakan pekerja tetap dengan menggunakan perjanjian kerja lisan. Pekerja sebelum menjadi pekerja tetap, telah dilakukan masa percobaan oleh pemilik restoran selama tiga bulan sesuai dengan kompetensi yang ditulisakan pada surat lamaran. Perjanjian lisan yang telah disepakati memuat mengenai hal-hal yang umum antara pemberi kerja beserta pekerja yang akan melakukan pekerjaan yang telah disepakati, seperti gaji yang diberikan tidak dibawah UMK (Upah Minimum Kabupaten) serta skill yang dimiliki oleh setiap pekerja, waktu kerja 8 jam selama 6 hari dalam 1 minggu, mendapatkan tanggungan berupa asuransi BPJS Kesehatan dan asuransi keselamatan kerja, bagi pekerja wanita telah disepakatai mengenai cuti melahirkan dalam 2 bulan sebelum dan 2 bulan sesudah melahirkan akan diberikan cuti.

Pemilik restoran yakni ibu Ni Wayan Astiti pada 15 April 2020 menyatakan bahwa, mengenai waktu kerja di Sayan Point Restaurant pekerja melakukan pekerjaan 8 jam sehari selama 6 hari dalam 1 minggu, pekerja diberikan libur dalam 1 hari dalam seminggu dengan sistem libur yang diberikan antara pekerja berbeda hari terhadap pekerja lain. Pekerja melaksanakan pekerjaan telah ditentukan oleh pemberi kerja dalam 2 shift, yakni pagi dan sore. Apabila pekerja mendapatkan shift pagi maka waktu kerjanya mulai pada pukul 07.00 WITA sampai 15.00 WITA, sedangkan pekerja yang mendapatkan shift sore maka waktu kerjanya mulai pada 15.00 WITA sampai 23.00 WITA, waktu istirahat yang telah ditentukan oleh pemberi kerja selama kurang lebih 1

17 Yulianita, Wulan, and Kadek Sarna. "Tinjauan Yuridis Terhadap Jangka Waktu Pembayaran Upah Kerja Lembur Bagi Pekerja Tetap." Kertha Semaya: Journal Ilmu Hukum 5. no. 2 (2016) : $1-5$. 
jam diluar waktu kerja yang telah disepakati. Pekerja yang melakukan pekerjaan yang melebihi waktu kerja, tidak mendapatkan makan namun pekerja mendapatkan minum pada saat melakukan kerja lembur. Pekerja mendapatkan makan hanya 1 kali selama bekerja yaitu pada jam istirahat. Pekerja menerima upah pada awal bulan secara tunai dengan diberikan menggunakan amplop. Pekerja mendapatkan upah diatas UMK, setiap bulan akan mendapatkan besaran upah yang berbeda setiap pekerja berdasarkan skill yang dimiliki oleh setiap pekerja serta tergantung pada penghasilan restoran. Pekerja mendapatkan upah sesuai dengan kemampuan yang dimiliki, pekerja mendapatkan upah paling rendah sebesar Rp. 2.900.000,- sampai Rp. 3.200.000,mengenai pembayaran upah kerja yang melebihi batas waktu kerja merupakan loyalitas pekerja kepada restoran. Pekerja tidak mendapatkan rincian mengenai pembayaran upah oleh pemilik restoran.

\subsection{Faktor Penghambat Dalam Pelaksanaan Terhadap Pemenuhan Hak Pekerja Yang Melebihi Batas Waktu Kerja Pada Sayan Point Restaurant}

Pelaksanaan efektivitas hukum dalam kehidupan masyarakat, dapat diukur dengan keberhasilan hukum tersebut, seberapa maksimal peraturan tersebut telah berlangsung serta tepat sasaran untuk menyelesaikan suatu permasalahan yang terjadi. ${ }^{18}$ Dalam pelaksanaan suatu subjek atau objek yang akan diterapkan apabila terjadi suatu hambatan untuk diterapkan dapat dikatakan sebagai faktor penghambat. Ketentuan mengenai norma hukum yang mengatur tentang ketenagakerjaan telah diatur dalam UU Ketenagakerjaan, sehingga masing-masing perusahaan yang mempekerjakan pekerja wajib mengikuti aturan tersebut. Suatu peraturan tentang ketenagakerjaan tidak dapat dilaksanakan oleh pemberi kerja secara penuh maka akan diberikan sanksi. Hambatan yang terjadi ketika melaksanakan perlindungan hukum oleh pemberi kerja tidak dapat melaksanakan peraturan yang berlaku secara maksimal. ${ }^{19}$ Perjanjian kerja yang merujuk pada Pasal 1320 KUHPerdata serta Pasal 52 UU Ketenagakerjaan, adapun perjanjian yang telah disepakati oleh pekerja dan pemberi kerja berupa perjanjian lisan ataupun perjanjian tertulis dapat menjadi salah satu syarat utama sebagai dasar perjanjian diantara kedua belah pihak. ${ }^{20}$

Gaji merupakan suatu hak yang diterima oleh seseorang atas jasa yang telah dilakukan dalam melaksanakan pekerjaan yang merupakan kewajiban perusahaan sehingga perusahaan wajib memberikan upah sesuai dengan jasa kerja pekerja. Besar kecilnya upah yang diterima oleh pekerja tergantung dari nilai barang atau jasa yang telah dihasilkan. ${ }^{21}$ Kebijakan upah untuk melindungi pekerja oleh pemberi kerja telah ditentukan dalam undang-undang ketenagakerjaan dalam Pasal 88 ayat (3). Pembayaran upah saat lembur menjadi hak pekerja, namun berdasarkan wawancara pekerja yakni I Ketut Agus Adi Saputra menyatakan tidak mendapatkan upah lembur.

18 Sari, Made Nadya Pradnya, I. Made Udiana, and I. Nyoman Mudana. "Pelaksanaan Perjanjian Kerja Waktu Tertentu (PKWT) Pada Villa The Seminyak Oasis." Kertha Semaya: Journal Ilmu Hukum 2, no. 2 (2018): 1-13.

19 Apriyanti, Putu Lia, I. Nyoman Mudana, and I. Made Pujawan. "Pelaksanaan Kewajiban Pengusaha Terhadap Pekerja Perempuan Yang Bekerja Pada Malam Hari Di Hotel Maya Ubud." Kertha Semaya: Journal Ilmu Hukum 3, no. 2 (2018): 1-15.

20 Ardiyanti, AA Mira Crysinta, and I. Wayan Novy Purwanto. "Akibat Hukum Bagi Pondok Wisata Nadia Pansion Terhadap Pekerja Yang Kelebihan Batas Waktu Kerja." Kertha Negara: Journal Ilmu Hukum 7, no. 11 (2019): 1-11.

21 Is, Muhamad Sadi, Sobandi. Hukum Ketenagakerjaan Di Indonesia (Jakarta, Kencana, 2020), 207. 
Upah yang diterima hanya pada awal bulan, pemilik restoran tidak memberikan rincian berapa gaji pokok serta upah yang lainnya. Pekerja tidak mengetahui bahwa dalam pembayaran gaji oleh perusahaan, perusahaan wajib memberikan rincian mengenai gaji yang diberikan. Pasal 17 ayat (2) Peraturan Pemerintah Nomor 78 Tahun 2015 Tentang Pengupahan menyatakan "Pengusaha wajib memberikan bukti pembayaran Upah yang memuat rincian Upah yang diterima oleh Pekerja pada saat Upah dibayarkan". Pekerja hanya mengetahui bahwa upah yang dibayarkan telah dipotong pembayaran BPJS Kesehatan dan asuransi kecelakaan kerja. Dalam melakukan interview saat melakukan kesepakatan kerja yang menggunakan perjanjian kerja lisan, pekerja hanya mengetahui bahwa akan mendapatkan pekerja sesuai UMK dan skill yang dimiliki, pemberi kerja tidak menyinggung mengenai besaran upah kerja lembur yang akan dibayarkan. Pekerja tidak mengetahui bahwa mengenai besaran upah lembur terdapat cara penghitungannya yang telah diatur dalam Kepmenakertrans No. KEP102/MEN/IV/2004 Tahun 2004 Tentang Waktu Kerja Lembur Dan Upah Kerja Lembur, Pasal 8 ayat (1) menyatakan "Perhitungan upah lembur didasarkan pada upah bulanan" dan ayat (2) menyatakan "Cara menghitung upah sejam adalah 1/173 kali upah sebulan".

Penulis bertemu dengan salah satu pekerja yang bernama Ni Made Sariani pada 13 April 2020 pada Sayan Point Restaurant, menyatakan bahwa semua pekerja disini bekerja selama 8 jam dan 1 jam untuk istirahat diluar jam kerja selama 6 hari dalam 1 minggu. Pekerja tidak mendapatkan makan saat lembur namun untuk minum diberikan oleh pihak restoran, biasanya pekerja melakukan kerja lembur 3 sampai 4 jam. Kepmenakertrans No. KEP-102/MEN/IV/2004 Tahun 2004 Tentang Waktu Kerja Lembur Dan Upah Kerja Lembur Pada Pasal 7 telah ditentukan bahwa pekerja yang melakukan waktu kerja lembur, perusahaan memiliki kewajiban memberikan upah terhadap lebihnya waktu untuk bekerja yang dikerjakan oleh pekerja, istirahat yang cukup kemudian memberikan makan beserta minum minimal 1.400 kalori dalam melakukan kerja lembur lebih dari 3 jam. Tidak adanya perintah perintah tertulis yang dibuat berupa daftar bagi pekerja yang akan melakukan kerja lembur oleh pemilik restoran, namum pemilik restoran melakukan perintah secara lisan. Jika melihat ketentuan peraturan Kepmenakertrans No. KEP-102/MEN/IV/2004 Tahun 2004 Tentang Waktu Kerja Lembur Dan Upah Kerja Lembur Pada Pasal 6, telah ditentukan bahwa perusahaan apabila ingin mempekerjakan pekerja dengan sistem lembur harus dibuatkan dengan perintah tertulis dalam bentuk draf, kemudian ditandatangani oleh pekerja yang akan lembur. Terjadinya ketidaksesuaian antara peraturan perundangundangan dengan fakta yang terjadi dilapangan. Kurangnya pemahaman oleh pekerja terkait hak yang dimiliki pekerja seharusnya untuk didapatkan saat lembur sebagaimana diatur dalam undang-undang maupun peraturan pelaksananya menjadi salah satu faktor penghambat pelaksanaan hak bagi pekerja yang melebihi batas waktu kerja.

Faktor-faktor penghambat terhadap penerapan pemenuhan hak pekerja yang melebihi waktu kerja pada Sayan Point Restaurant, antara lain:

1. Pelaksanaan hak pekerja saat lembur banyak terjadi hambatan dalam pelaksanaan pemberian hak pekerja saat lembur. Mengenai pemberian makan saat lembur yang lebih dari 3 jam, pemilik restoran dan pekerja kurang mengetahui mengenai pengaturan tersebut.

2. Mengenai upah lembur pekerja, pemenuhan upah yang diberikan oleh pemilik restoran cukup pada gaji pokok yang didasarkan atas skill yang dimiliki oleh setiap pekerja. 
3. Pemilik restoran kurang mengetahui mengenai pemberian upah lembur serta tata cara penghitungannya kepada para pekerja, mengenai pemberian gaji yang seharusnya diberikan rincian oleh perusahaan juga tidak memberikan, kurangnya pemahaman mengenai peraturan yang sedang berlaku menjadi alasanya tidak terpenuhinya hak pekerja. Sayan Point Restauran merupakan usaha yang bergerak dalam penyediaan makanan yang mendapatkan penghasilan dari banyak atau sedikitnya tamu yang datang restoran.

Berdasarkan hasil wawancara dengan ibu Ni Wayan Astiti sebagai pemilik restoran, menyatakan bahwa pelaksanaan pemenuhan pekerja pada Sayan Point Restaurant sudah berjalan baik, namun terdapat suatu yang tidak berjalan efektif terhadap pemenuhan hak pekerja lembur serta pembayaran upah lembur. Sayan Point Restaurant berusaha untuk memenuhi hak pekerjanya dari sisi kesejahteraan dengan pemberian upah sesuai dengan UMK dan memberikan perlindungan kesehatan dengan pemberian BPJS Kesehatan dan asuransi kecelakaan kerja.

\section{Kesimpulan}

Pekerja berhak dalam memperoleh suatu perlindungan yang sama didalam hukum, pekerja memiliki hak dasar dilakukan untuk menjamin agar pekerja tidak mendapatkan perlakuan yang merugikan dirinya seperti tindakan diskriminasi serta tidak mendapatkan kesejahteraan ataupun keselamatan kerja bagi pekerja. Pekerjaan diluar jam kerja oleh pekerja, yang telah ditentukan oleh pemberi kerja maka waktu kerja tersebut dapat dikatakan sebagai lembur, sehingga pekerja memiliki hak untuk memperoleh upah lembur diluar gaji pokok. Pekerja yang melebihi jam kerja untuk melakukan pekerjaan, perusahaan sebagai pemberi kerja memiliki kewajiban untuk melakukan pembayaran upah kerja lembur maupun pemenuhan hak yang menjadi tanggung jawab pemberi kerja. Pemberian gaji bagi pekerja seharusnya diberikan rincian mengenai gaji yang diberikan. Faktor penghambat dalam pemenuhan hak pekerja yang melebihi batas waktu kerja terjadi karena kurang mengetaui mengenai adanya pengaturan yang mengatur tentang hak-hak pekerja saat lembur. Saran yang dapat disampaikan terhadap Sayan Point Restauran yakni, seharusnya pemenuhan terhadap hak pekerja yang melebihi waktu kerja dipenuhi berdasarkan peraturan yang telah ada, sehingga kesejahteraan terhadap para pekerja yang telah mengeluarkan tenaganya untuk melakukan kerja yang melebihi waktu kerja atau yang sering disebut dengan kerja lembur. Pekerja dan pemberi kerja lebih dapat meningkatkan kesadaran hukum untuk mengetahui terhadap hak serta kewajiban pada masing-masing pihak.

\section{DAFTAR PUSTAKA}

\section{Buku}

Husni, Lalu. Pengantar Hukum Ketenagakerjaan Edisi Revisi (Depok, PT RajaGrafindo Persada, 2019).

Is, Muhamad Sadi, Sobandi. Hukum Ketenagakerjaan Di Indonesia ( Jakarta, Kencana, 2020).

Wiradipradja, E. Saefullah. Penuntun Praktis Metode Penelitian Dan Penulisan Karya Ilmiah Hukum Cetakan Ke 2 (Bandung, CV Keni Media, 2016).

\section{Jurnal}


Andriani, Ni Made Rosa Dita, and I Ketut Sudantra. "Pelaksanaan Perlindungan Hukum Terhadap Hak Tenaga Kerja Kontrak Pada Hotel The Griya Sanur." Journal Ilmu Hukum 8, no. 4 (2020): 1-13.

Apriyanti, Putu Lia, I. Nyoman Mudana, and I. Made Pujawan. "Pelaksanaan Kewajiban Pengusaha Terhadap Pekerja Perempuan Yang Bekerja Pada Malam Hari Di Hotel Maya Ubud." Kertha Semaya: Journal Ilmu Hukum 3, no. 2 (2018): 115.

Ardiyanti, AA Mira Crysinta, and I. Wayan Novy Purwanto. "Akibat Hukum Bagi Pondok Wisata Nadia Pansion Terhadap Pekerja Yang Kelebihan Batas Waktu Kerja." Kertha Negara: Journal Ilmu Hukum 7, no. 11 (2019): 1-11.

Cesmi, Pande Md. Meby Elbina Devita Cesmi, and A.A. Gede Agung DharmaKusuma. "Perlindungan Hukum Terhadap Tenaga Kerja Yang Bekerja Melebihi Batas Waktu Lembur Pada Perusahaan PT. Bintang Merapi Denpasar." Journal Ilmu Hukum 01, no. 11 (2013): 1-15.

Ismono, Joko. "Hubungan Kerja dalam Perspektif HAM, Ekonomi, dan Pembangunan." Halu Oleo Law Review 2, no 1 (2018): 354-370.

Jayanti, Feranika Anggasari, and I. Made Udiana. "Perlindungan Hukum Terhadap Tenaga Kerja Perempuan Pada Malam Hari Di Hotel Kelas Melati (Studi Pada Hotel Jayagiri Denpasar)." Kertha Semaya: Journal Ilmu Hukum 5, no. 2 (2017): 1-6.

Mantiri, Frangky F. "Perlindungan Hukum Pemda Sulawesi Utara Atas Hak Dasar Tenaga Kerja Sebagai Wujud Perlindungan Hak Asasi Manusia." Lex Et Societatis 6, no. 3 (2018): 1-9.

Opriyana, I. Ketut Agus Surya, I. Made Udiana, and I. Nyoman Mudana. "Pelaksanaan Ketentuan Upah Lembur Pekerja Pada CV. Bali Aquarium." Kertha Semaya: Journal Ilmu Hukum 6, no. 12 (2019): 1-14.

Pratama, Ida Bagus Gede, and I. Nyoman Darmadha. "Pelaksanaan Istirahat Kerja Bagi Pekerja Perempuan Pada Ramayana Hotel Denpasar." Kertha Negara: Journal Ilmu Hukum 7, no. 10 (2019) : 1-15.

Putri, Ni Nyoman Nityarani Sukadana, and Ni Ketut Supasti Dharmawan. "Pengaturan Hak Pekerja Yang Di PHK Berkaitan Dengan Perusahaan Pailit." Kertha Semaya: Journal Ilmu Hukum 6, no. 11 (2018) : 1-15.

Rismansyah, Mohammad Robi, and Yasmin Hadid. "Hak Pekerja Perempuan Diskriminasi. "Perlindungan Hukum Terhadap Tenaga Kerja Perempuan Indonesia Di Tempat Kerja Dan Kaitannya Dengan Pembangunan Ekonomi Nasional." Padjajaran Jurnal Ilmu Hukum 7, no 2 (2019): 26-43.

Sari, Made Nadya Pradnya, I. Made Udiana, and I. Nyoman Mudana. "Pelaksanaan Perjanjian Kerja Waktu Tertentu (PKWT) Pada Villa The Seminyak Oasis." Kertha Semaya: Journal Ilmu Hukum 2, no. 2 (2018): 1-13.

Setiawan, Andre. "Pemenuhan Hak Pekerja Outsourcing Yang Bekerja Melebihi Waktu Kerja Normal Di PT Trakindo Utama Balikpapan." Universitas Atma Jaya Yogyakarta (2014): 1-9.

Sudewi, Komang Ritha, and A.A. Ngurah Wirasila. "Penyelesaian Sengketa Perjanjian Kerja Pada Pekerja Di Hotel Kubu Bali House Di Kabupaten Badung." Kertha Semaya: Journal Ilmu Hukum 4, no. 2 (2018): 1-14.

Sumandika, I. Wayan Agus, and I. Nyoman Mudana. "Pelaksanaan Perlindungan Hukum Bagi Pekerja Perempuan Pada Besakih Beach Hotel Sanur Di Denpasar." Kertha Semaya: Journal Ilmu Hukum 7, no. 2 (2019) : 1-20.

Tricahya, Anak Agung Ngurah Gede Agung, Yoga Kumara, and I. Wayan Novy Purwanto. "Korelasi Antara Waktu Kerja Lembur Terhadap Upah Yang Terjadi 
Di Lingkungan Masyarakat Waribang." Kertha Semaya: Journal Ilmu Hukum 4, no. 1 (2018) : 1-14.

Yulianita, Wulan, and Kadek Sarna. "Tinjauan Yuridis Terhadap Jangka Waktu Pembayaran Upah Kerja Lembur Bagi Pekerja Tetap." Kertha Semaya: Journal Ilmu Hukum 5. no. 2 (2016) : 1-5.

PERATURAN PERUNDANG - UNDANGAN

Undang-Undang Dasar Negara Republik Indonesia Tahun 1945

Kitab Undang-Undang Hukum Perdata

Undang-Undang Republik Indonesia Nomor 13 Tahun 2003 Tentang Ketenagakerjaan (Lembaran Negara Republik Indonesia Tahun 2003 Nomor 39, Tambahan Lembaran Negara Republik Indonesia Nomor 4279).

Peraturan Pemerintah Republik Indonesia Nomor 78 Tahun 2015 Tentang Pengupahan ( Lembaran Negara Republik Indonesia Tahun 2015 Nomor 237, Tambahan Lembaran Negara Republik Indonesia Nomor 5747).

Keputusan Menteri Tenaga Kerja Dan Transmigrasi Republik Indonesia Nomor KEP.102/MEN/VI/2004 Tentang Waktu Kerja Lembur Dan Upah Kerja Lembur. 